Jurnal Keperawatan Silampari

Volume 5, Nomor 1, Desember 2021

e-ISSN: 2581-1975

p-ISSN: 2597-7482

DOI: https://doi.org/10.31539/jks.v5i1.3033

\title{
PEMBERIAN NUTRISI ENTERAL SEBAGAI KONTROL GLIKEMIK PADA PASIEN KRITIS DI UNIT PERAWATAN INTENSIF
}

\author{
Firman Dwi Cahyo ${ }^{1}$, Cecep Eli Kosasih ${ }^{2}$, Ristina Mirwanti ${ }^{3}$ \\ Universitas Padjadjaran ${ }^{1,2,3}$ \\ fdcfirman@gmail.com ${ }^{1}$
}

\begin{abstract}
ABSTRAK
Penelitian ini bertujuan untuk mengetahui metode pemberian nutrisi enteral yang efektif dalam mempertahankan keseimbangan kadar glukosa darah dan/atau kontrol glikemik. Penelitian ini menggunakan metode narrative literature review dengan memasukkan kata kunci ke dalam database Pubmed, Science Direct, CINAHL, Wiley dan ProQuest. Hasil penelitian menunjukkan bahwa dari hasil pencarian didapatkan 569 artikel dan diperoleh 10 artikel yang relevan dan memenuhi syarat, kemudian diekstraksi dengan metode DSVIA. Pemberian nutrisi enteral dengan metode continuous dapat menurunkan rata-rata kadar glukosa darah atau mengurangi kejadian hiperglikemia. Kemudian metode intermiten secara signifikan lebih sedikit terjadi hipoglikemia selama periode makan, mencegah hipoglikemia selama periode puasa serta dapat menurunkan kebutuhan insulin. Simpulan, pemberian nutrisi enteral perlu modifikasi agar pemberian nutrisi dan waktu pemberian insulin dapat tepat guna dan efektif didalam mengontrol kadar glukosa pasien kritis.
\end{abstract}

Kata Kunci: Bolus Feeding, Continuous Feeding, Glukosa Darah, Intermittent Feeding, Nutrisi Enteral

\begin{abstract}
This study aims to determine how to provide nutrition that effectively maintains the balance of blood glucose levels and glycemic control. This study uses a narrative literature review method by entering keywords into the Pubmed, Science Direct, CINAHL, Wiley, and ProQuest databases. The results showed that from the search results of 569 articles and obtained ten relevant and qualified pieces, then extracted using the DSVIA method. Provision of nutrition with the continuous method can lower the average blood glucose or reduce the incidence of hyperglycemia. Then the intermittent process significantly reduces hypoglycemia during the meal period, prevents hypoglycemia during the fasting period, and can reduce insulin requirements. In conclusion, enteral nutrition needs to be modified so that nutrition and insulin administration time can be practical and effective in controlling critical sugar levels.
\end{abstract}

Keywords: Bolus Feeding, Continuous Feeding, Blood Glucose, Intermittent Feeding, Enteral Nutrition 


\section{PENDAHULUAN}

Pasien kritis rentan mengalami stress fisiologis yang mengakibatkan perubahan metabolisme, gangguan homeostatis hormonal dan berdampak pada kejadian disglikemik yang dapat berupa hiperglikemia, hipoglikemia dan/atau variabilitas glukosa ditandai dengan perubahan fluktuasi kadar glukosa darah pada pasien kritis (Hutagaol \& Hamidi, 2020). Kondisi hiperglikemia dengan kadar glukosa darah >140 $\mathrm{mg} / \mathrm{dl}$ dan HbA1c < 6,5 serta yang ekstrim >300 mg/dl dapat meningkatkan risiko kematian hingga 42,5\%. Disisi lain, hipoglikemik dengan kadar glukosa darah <40 $\mathrm{mg} / \mathrm{dl}$ juga memperlihatkan fenomena yang sama dengan risiko kematian hingga 3 kali lipat lebih tinggi (Amaliah, 2021; Kembuan, 2018).

Salah satu faktor pencetus perubahan status glikemik yakni masalah nutrisi. Hal ini perlu diantisipasi dengan inisiasi dini pemberian nutrisi enteral 24-48 jam di awal perawatan intensif termasuk pasien dengan kebutuhan ventilator (Ferrie et al., 2018). Metode pemberian nutrisi enteral berperan penting dalam pencapaian target pemenuhan nutrisi serta direkomendasikan guna menurunkan kondisi hiperkatabolisme, mengurangi produksi sitokin pro-inflamasi dan menjaga sistem enzim enterohepatik (Dewi \& Supriatna, 2021; Mahakrishna et al., 2020). Dalam hal ini pemberian nutrisi enteral ditentukan berdasarkan respon asupan dan toleransi pasien kritis terhadap feeding tubel nutrisi enteral yang diberikan (Taslim et al., 2020).

Berbagai metode pemberian nutrisi enteral dapat dilakukan, diantaranya dengan metode terus menerus dan berselang atau terputus-putus. Secara terus menerus dengan continuous feeding yakni pasien diberikan nutrisi enteral dengan pompa pengumpan atau syringe pump selama 24 jam penuh serta terdapat jeda beberapa jam tanpa pemberian nutrisi enteral pada metode cyclic feeding. Kemudian pada metode berselang atau terputus-putus dengan intermittent feeding yakni metode pemberian nutrisi enteral dengan atau tanpa pompa pengumpan/syringe pump yang diberikan 4-6 kali sehari selama 20-60 menit. Metode bolus feeding atau gravity drip yaitu metode pemberian nutrisi enteral dengan jarum suntik/spuit yang disambungkan ke selang gastric dengan kecepatan mengikuti gaya gravitasi diberikan 4-6 kali sehari selama 5-10 menit (Hutagaol \& Hamidi, 2020; Bear et al., 2018; Ichimaru, 2018).

Pemberian nutrisi enteral bukanlah bebas dari komplikasi secara metabolik seperti peningkatan kadar glukosa darah, ketidakseimbangan elektrolit dan refeeding syndrome. Hiperglikemia telah dilaporkan pada $30 \%$ pasien yang menerima nutrisi enteral (Anggorotomo \& Kestriani, 2020). Hiperglikemia pada pasien kritis tanpa penyakit diabetes mellitus merupakan kejadian umum diperawatan intensif. Sebanyak $90 \%$ pasien kritis mengalami gangguan toleransi glukosa atau resistensi insulin. Risiko hiperglikemia pada pemberian nutrisi enteral bahkan lebih tinggi pada pasien yang tidak terdiagnosis diabetes mellitus sebelumnya dan terbukti mengalami peningkatan risiko kematian dibandingkan dengan mereka yang menderita diabetes mellitus (Kembuan, 2018).

Kejadian disglikemia baik hiperglikemia, hipoglikemia dan variabilitas glikemik tinggi bersinergis pada perburukan kondisi vital pasien kritis, sehingga perlu pemilihan metode pemberian nutrisi enteral yang tepat. Beberapa studi literatur telah membahas berbagai metode pemberian nutrisi enteral yang dapat dilakukan pada pasien kritis di ICU namun belum terdapat tinjauan yang menelaah bukti metode pemberian nutrisi yang lebih efektif dalam menstabilkan status glikemik. Tuntutan penatalaksanaan manajemen perawatan kritis dalam pemenuhan nutrisi telah meningkatkan minat dalam menguji metode untuk pemberian nutrisi enteral khususnya dalam mempertahankan 
keseimbangan glikemik (Bear et al., 2018). Mengingat kendali glukosa yang penting terhadap luaran pasien kritis di Intensive Care Unit (ICU), maka diperlukan sebuah review guna mendapatkan pilihan metode pemberian nutrisi yang efektif di dalam mengontrol glikemik pasien kritis dan memberikan efek positif dalam penalataksaan komprehensif pasien kritis (Anggorotomo \& Kestriani, 2020). Narrative review ini bertujuan untuk mengetahui metode pemberian nutrisi enteral yang efektif dalam mempertahankan keseimbangan kadar glukosa darah dan/atau kontrol glikemik.

\section{METODE PENELITIAN}

Penelitian ini menggunakan metode narrative literature review melalui analisis yang komprehensif, kritis, dan objektif. Kata kunci ((("Enteral Nutrition"[Mesh]) AND (Continuous Feeding)) AND (Intermittent Feeding) OR (Bolus Feeding)) AND (Blood Sugar) dimasukkan ke dalam database yaitu Pubmed, Science Direct, CINAHL, Wiley dan ProQuest.

Hasil pencarian pada database dengan advance search ditemukan sebanyak 632 artikel. Setelah itu, melakukan cek duplikasi sehingga tersisa sebanyak 569 artikel. Analisa artikel berfokus pada metode pemberian nutrisi enteral dengan outcome terhadap kadar glukosa darah, diseleksi melalui skrining judul dan abstrak sehingga didapatkan 36 artikel yang relevan. Kemudian dilakukan penilaian kelayakan artikel dengan membaca full-text dan memilah artikel sesuai dengan fokus dan tujuan tinjauan literatur. Diperoleh 10 artikel yang relevan dan memenuhi syarat, diekstraksi dengan metode DSVIA (Design, Sample, Variable, Instrument dan Analysis).
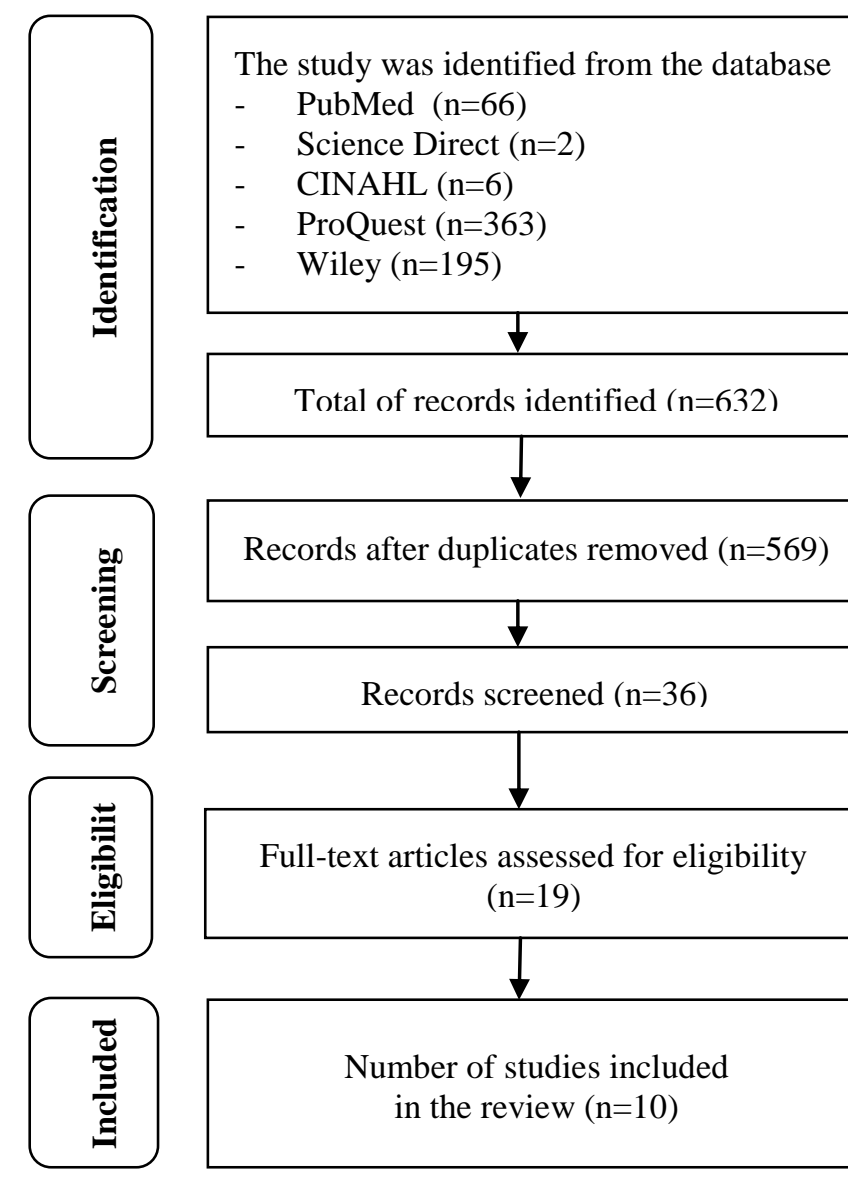

Total of records identified $(\mathrm{n}=632)$

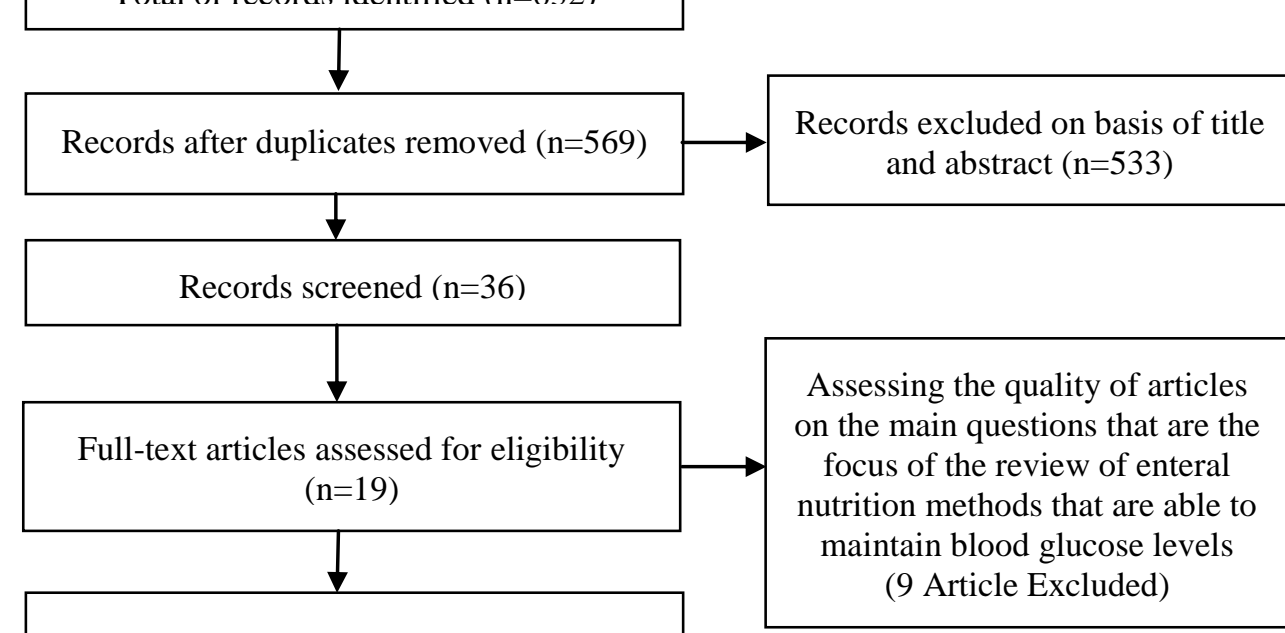

Number of studies included in the review $(n=10)$ 
HASIL PENELITIAN

Tabel. 1

Hasil Kajian Artikel $(\mathrm{n}=10)$

\begin{tabular}{|c|c|c|c|c|}
\hline No & $\begin{array}{l}\text { Pengarang, Judul, } \\
\text { Jenis Literatur }\end{array}$ & Tahun & Tujuan & Hasil Temuan \\
\hline 1 & $\begin{array}{l}\text { Murphy et al., } \\
\text { Glycaemic control } \\
\text { in insulin requiring } \\
\text { diabetes patients } \\
\text { receiving exclusive } \\
\text { enteral tube } \\
\text { feeding in an acute } \\
\text { hospital setting, } \\
\text { Retrospective } \\
\text { Analysis }\end{array}$ & 2013 & $\begin{array}{l}\text { Mengoptimalkan } \\
\text { kontrol glikemik } \\
\text { untuk insulin yang } \\
\text { membutuhkan } \\
\text { individu selama } \\
\text { pemberian } \\
\text { makanan enteral } \\
\text { adalah penting } \\
\text { tetapi sulit. Kami } \\
\text { membandingkan } 3 \\
\text { rejimen insulin } \\
\text { dengan tujuan } \\
\text { meningkatkan } \\
\text { kontrol glukosa dan } \\
\text { mengurangi } \\
\text { hipoglikemia }\end{array}$ & $\begin{array}{l}\text { Dalam penelitian belum } \\
\text { menunjukkan perbedaan } \\
\text { dalam kontrol glukosa } \\
\text { secara keseluruhan atau } \\
\text { perbedaan variabilitas } \\
\text { glukosa antara ketiga } \\
\text { kelompok tetapi } \\
\text { menunjukkan perbedaan } \\
\text { dalam tingkat hipoglikemia. } \\
\text { Hipoglikemia secara } \\
\text { signifikan lebih sedikit } \\
\text { selama periode makan pada } \\
\text { kelompok intermitten } \\
\text { feeding }(p<0.001) .\end{array}$ \\
\hline 2 & $\begin{array}{l}\text { Maurya et al., } \\
\text { Comparison of } \\
\text { Respiratory } \\
\text { Quotient and } \\
\text { Resting Energy } \\
\text { Expenditure in } \\
\text { Two Regimens of } \\
\text { Enteral Feeding - } \\
\text { Continuous vs. } \\
\text { Intermittent in } \\
\text { Head-Injured } \\
\text { Critically Ill } \\
\text { Patients, } \\
\text { Randomized Study }\end{array}$ & 2011 & $\begin{array}{l}\text { Untuk mempelajari } \\
\text { efek rejimen makan } \\
\text { terus menerus vs } \\
\text { intermiten pada } \\
\text { pasien cedera } \\
\text { kepala pada } \\
\text { ventilasi mekanis } \\
\text { pada RQ dan REE }\end{array}$ & $\begin{array}{l}\text { Tidak ada perbedaan yang } \\
\text { signifikan dalam tingkat } \\
\text { gula darah (diukur setiap } 4 \\
\text { jam) antara kedua kelompok } \\
(p>0,05)\end{array}$ \\
\hline 3 & $\begin{array}{l}\text { Seyyedi et al., } \\
\text { Comparison of the } \\
\text { Effect of Enteral } \\
\text { Feeding through } \\
\text { the Bolus and } \\
\text { Continuous } \\
\text { Methods on Serum } \\
\text { Phosphorus and } \\
\text { Glucose Levels in } \\
\text { Patients with } \\
\text { Mechanical } \\
\text { Ventilation : A } \\
\text { Randomized } \\
\text { Clinical Trial, } \\
\text { Clinical Trial }\end{array}$ & 2020 & $\begin{array}{l}\text { Untuk } \\
\text { membandingkan } \\
\text { efek bolus dan } \\
\text { metode pemberian } \\
\text { makanan enteral } \\
\text { kontinu pada fosfor } \\
\text { serum dan kadar } \\
\text { glukosa pada } \\
\text { pasien dengan } \\
\text { ventilasi mekanis }\end{array}$ & $\begin{array}{l}\text { Tidak terdapat perbedaan } \\
\text { bermakna antara kadar } \\
\text { glukosa dari hari ke } 1 \\
\text { sampai hari ke } 7 \text { pada } \\
\text { kelompok kontrol }(p=0,33) \\
\text { dan kelompok intervensi }(p \\
=0,086) \text {. }\end{array}$ \\
\hline 4 & $\begin{array}{l}\text { Shahriari et al., } \\
\text { Comparison of the } \\
\text { Effects of Enteral } \\
\text { Feeding Through } \\
\text { the Bolus and }\end{array}$ & 2015 & $\begin{array}{l}\text { Untuk } \\
\text { membandingkan } \\
\text { efek pemberian } \\
\text { makanan enteral } \\
\text { melalui bolus dan }\end{array}$ & $\begin{array}{l}\text { Pada kelompok penelitian, } \\
\text { rata-rata gula darah } \\
\text { menurun secara signifikan } \\
\text { pada hari keempat, } \\
\text { dibandingkan dengan hari }\end{array}$ \\
\hline
\end{tabular}




\begin{tabular}{|c|c|c|c|}
\hline & $\begin{array}{l}\text { Continuous } \\
\text { Methods on Blood } \\
\text { Sugar and } \\
\text { Prealbumin Levels } \\
\text { in ICU Inpatients, } \\
\text { Clinical Trial }\end{array}$ & $\begin{array}{l}\text { metode kontinu } \\
\text { pada kadar gula } \\
\text { darah dan } \\
\text { prealbumin di } \\
\text { antara pasien rawat } \\
\text { inap ICU }\end{array}$ & $\begin{array}{l}\text { pertama }(p=0,03, \mathrm{~F}=3,85) \\
\text { dan ketiga }(p=0,01, \mathrm{~F}= \\
3,15) . \text { Pada kelompok } \\
\text { kontrol, rata-rata gula darah } \\
\text { meningkat dari hari } \\
\text { pertama. Itu secara } \\
\text { signifikan lebih tinggi pada } \\
\text { kelompok kontrol pada hari } \\
\text { kedua }(p=0,02, \mathrm{~F}=3,55), \\
\text { dibandingkan dengan } \\
\text { kelompok studi. }\end{array}$ \\
\hline 5 & $\begin{array}{l}\text { (Evans et al., 2016) } \\
\text { Continuous Versus } \\
\text { Bolus Tube Feeds : } \\
\text { Does the Modality } \\
\text { Affect Glycemic } \\
\text { Variability, Tube } \\
\text { Feeding Volume, } \\
\text { Caloric Intake, or } \\
\text { Insulin } \\
\text { Utilization ?, } \\
\text { Clinical Trial }\end{array}$ & $\begin{array}{l}\text { Untuk meneliti } \\
\text { apakah ada } \\
\text { perbedaan dalam } \\
\mathrm{GV} \text {, penggunaan } \\
\text { insulin, volume TF, } \\
\text { dan pengiriman } \\
\text { kalori antara pasien } \\
\text { perawatan intensif } \\
\text { yang menerima } \\
\text { BTF versus CTF }\end{array}$ & $\begin{array}{l}\text { Saat memeriksa data agregat } \\
\text { untuk kelompok gabungan, } \\
\text { variabilitas glikemik } \\
\text { menurun dari waktu ke } \\
\text { waktu, sehingga variabilitas } \\
\text { glikemik selama epoch } \\
\text { pertama secara signifikan } \\
\text { lebih besar daripada epoch } \\
\text { terakhir }(p<0,05)\end{array}$ \\
\hline 6 & $\begin{array}{l}\text { Sjulin et al., } \\
\text { Intermittent } \\
\text { Gastric Feeds } \\
\text { Lower Insulin } \\
\text { Requirements } \\
\text { without Worsening } \\
\text { Dysglycemia: A } \\
\text { Pilot Randomized } \\
\text { Crossover Trial, } \\
\text { Prospective, } \\
\text { Nonblinded } \\
\text { Randomized } \\
\text { Controlled } \\
\text { Crossover Trial }\end{array}$ & $\begin{array}{l}\text { Untuk menguji } \\
\text { asupan lambung } \\
\text { intermiten } \\
\text { dalammenurunkan } \\
\text { kebutuhan insulin } \\
\text { tanpa } \\
\text { memperburuk } \\
\text { disglikemia }\end{array}$ & $\begin{array}{l}\text { Pasien kritis yang } \\
\text { membutuhkan infus insulin } \\
\text { memiliki kebutuhan insulin } \\
\text { yang berkurang ketika } \\
\text { diberi nutrisi enteral secara } \\
\text { intermittent ( } p=0.027 \text { ), } \\
\text { menurunkan rata-rata } \\
\text { insulin } 1,4 U / \text { pasien/jam } \\
\text { sedangkan metrik } \\
\text { disglikemia tidak } \\
\text { terpengaruh. }\end{array}$ \\
\hline 7 & $\begin{array}{l}\text { Mcnelly et al., } \\
\text { Effect of } \\
\text { Intermittent or } \\
\text { Continuous Feed } \\
\text { on Muscle Wasting } \\
\text { in Critical Illness a } \\
\text { Phase } 2 \text { Clinical } \\
\text { Trial, } \\
\text { Multicenter, } \\
\text { Single-Blinded } \\
\text { Randomized } \\
\text { Controlled Phase } 2 \\
\text { Trial }\end{array}$ & $\begin{array}{l}\text { Untuk mengetahui } \\
\text { Pemberian } \\
\text { Makanan } \\
\text { Intermiten atau } \\
\text { Kontinu terhadap } \\
\text { Pengecilan Otot } \\
\text { pada Penyakit } \\
\text { Kritis Uji Klinis } \\
\text { Fase } 2\end{array}$ & $\begin{array}{l}\text { Koefisien variasi untuk } \\
\text { glukosa plasma } \\
\text { konsentrasi lebih tinggi } \\
\text { pada intermiten daripada } \\
\text { continuous. } \\
\text { Tidak ada perbedaan dalam } \\
\text { jumlah hari di mana } \\
\text { hipoglikemik episode terjadi } \\
\text { antar kelompok. } \\
\text { Lebih banyak hari dengan } \\
\text { hiperglikemik yang } \\
\text { dilaporkan dengan } \\
\text { Intermittent Feeding } \\
\text { dibandingkan dengan } \\
\text { Continuous Feeding. } \\
\text { Penggunaan insulin tidak } \\
\text { berbeda antar kelompok. } \\
\text { Intermittent feeding } \\
\text { menerima sedikit insulin } \\
\text { eksogen dalam percobaan } 8 \text { - } \\
10 \text { hari dibanding dengan } \\
\text { continuous feeding }\end{array}$ \\
\hline
\end{tabular}




\begin{tabular}{|c|c|c|c|c|}
\hline 8 & $\begin{array}{l}\text { Ren et al., } \\
\text { Comparison of } \\
\text { Sequential Feeding } \\
\text { and Continuous } \\
\text { Feeding on the } \\
\text { Blood Glucose of } \\
\text { Critically Ill } \\
\text { Patients : A Non- } \\
\text { Inferiority } \\
\text { Randomized, } \\
\text { Controlled Trial } \\
\text { A non-inferiority } \\
\text { randomized } \\
\text { controlled trial }\end{array}$ & 2021 & $\begin{array}{l}\text { Untuk } \\
\text { membandingkan } \\
\text { efek pemberian } \\
\text { makan berurutan } \\
\text { (SF) dan pemberian } \\
\text { makan terus } \\
\text { menerus (CF) pada } \\
\text { glukosa darah } \\
\text { pasien yang sakit } \\
\text { kritis }\end{array}$ & $\begin{array}{l}\text { Kadar glukosa rata-rata } \\
\text { pada sequential feeding } \\
\text { tidak lebih tinggi dari pada } \\
\text { continuous feeding. Selain } \\
\text { itu, insiden hiperglikemia } \\
\text { lebih tinggi pada kelompok } \\
\text { continuous feeding daripada } \\
\text { kelompok sequential } \\
\text { feeding. Tidak ada } \\
\text { peningkatan intoleransi } \\
\text { makan pada sequential } \\
\text { feeding. } \\
\text { Sequential feeding mungkin } \\
\text { seaman continuous feeding } \\
\text { untuk pasien sakit kritis. }\end{array}$ \\
\hline 9 & $\begin{array}{l}\text { Chowdhury et al., } \\
\text { Effects of Bolus } \\
\text { and Continuous } \\
\text { Nasogastric } \\
\text { Feeding on Gastric } \\
\text { Emptying, Small } \\
\text { Bowel Water } \\
\text { Content, Superior } \\
\text { Mesenteric Artery } \\
\text { Blood Flow, and } \\
\text { Plasma Way } \\
\text { Crossover Study } \\
\text { Concentrations in } \\
\text { Healthy Adults, } \\
\text { Hormone A } \\
\text { Randomized, } \\
\text { Unblinded 2- }\end{array}$ & 2015 & $\begin{array}{l}\text { Untuk } \\
\text { mendemonstrasikan } \\
\text { efek pemberian } \\
\text { nasogastrik terus } \\
\text { menerus atau bolus } \\
\text { pada pengosongan } \\
\text { lambung, kadar air } \\
\text { usus halus, dan } \\
\text { aliran darah } \\
\text { splanknik yang } \\
\text { diukur dengan } \\
\text { magnetic resonance } \\
\text { imaging (MRI) } \\
\text { dalam konteks } \\
\text { perubahan sekresi } \\
\text { hormon } \\
\text { gastrointestinal } \\
\text { plasma. }\end{array}$ & $\begin{array}{l}\text { Terjadi peningkatan } \\
\text { konsentrasi plasma glukosa } \\
\text { pada kedua metode } \\
\text { pemberian nutrisi dengan } \\
\text { bolus dan continuous. } \\
\text { Konsentrasi glukosa vena } \\
\text { puncak diperoleh pada } 30 \\
\text { menit dengan penurunan } \\
\text { berikutnya. } \\
\text { Hanya ada sedikit } \\
\text { peningkatan konsentrasi } \\
\text { insulin dengan pemberian } \\
\text { continuous dibandingkan } \\
\text { dengan bolus. }\end{array}$ \\
\hline 10 & $\begin{array}{l}\text { Gonzalez et al., } \\
\text { Intermittent Versus } \\
\text { Continuous Enteral } \\
\text { Nutrition } \\
\text { Attenuates } \\
\text { Increases in Insulin } \\
\text { and Leptin During } \\
\text { Short - Term Bed } \\
\text { Rest, } \\
\text { Randomized }\end{array}$ & 2020 & $\begin{array}{l}\text { Untuk } \\
\text { membandingkan } \\
\text { respons endokrin } \\
\text { terhadap pemberian } \\
\text { nutrisi enteral } \\
\text { intermiten vs } \\
\text { kontinu selama } \\
\text { tirah baring jangka } \\
\text { pendek }\end{array}$ & $\begin{array}{l}\text { Tidak terdapat perbedaan } \\
\text { konsentrasi glukosa plasma } \\
\text { setelah hari ketujuh istirahat } \\
\text { di tempat tidur antara } \\
\text { kelompok intermittent dan } \\
\text { continuous. } \\
\text { Pada hari ketujuh } \\
\text { konsentrasi insulin plasma } \\
\text { meningkat pada continuous } \\
\text { dibandingkan intermittent. } \\
\text { Namun, konsentrasi } \\
\text { glukagon plasma mulai } \\
\text { meningkat pada kelompok } \\
\text { intermittent saja. Rasio } \\
\text { plasma insulin-to-glukagon } \\
\text { tetap stabil selama istirahat } \\
\text { di tempat tidur dengan } \\
\text { intermittent, tetapi } \\
\text { meningkat dengan } \\
\text { continuous sehingga pada } \\
\text { hari ke-6 dan } 7 \text {, rasio } \\
\text { insulin-to-glukagon plasma } \\
\text { lebih rendah intermittent } \\
\text { dibandingkan continuous. }\end{array}$ \\
\hline
\end{tabular}


Perbandingan intervensi tersebut diantaranya cyclic versus intermittent versus continuous, cyclic versus bolus, bolus versus continuous, intermittent versus continuous, dan sequential versus continuous.

\section{Cyclic versus Intermittent versus Continuous}

Berdasarkan tabel 1 penelitian murphy belum menunjukkan perbedaan dalam kontrol glukosa secara keseluruhan atau perbedaan variabilitas glukosa antara ketiga kelompok tetapi menunjukkan perbedaan dalam tingkat hipoglikemia. Hipoglikemia secara signifikan lebih sedikit selama periode makan pada kelompok metode intermiten feeding. Ada juga kecenderungan penurunan hipoglikemia selama periode puasa pada kelompok yang sama.

\section{Cyclic versus Bolus}

Penelitian yang dilakukan Maurya membandingkan metode cyclic yaitu pemberian nutrisi enteral $30 \mathrm{kkal} / \mathrm{kg} / \mathrm{hari}$ dengan bantuan pompa pengumpan atau feeding pump selama 18 jam/hari dengan jeda istirahat malam selama 6 jam dibandingkan dengan pemberian nutrisi $30 \mathrm{kkal} / \mathrm{kg} / \mathrm{hari}$ melalui metode bolus dengan menggunakan spuit $50 \mathrm{~mL}$ secara manual sebanyak 6 kali pemberian berselang 3 jam dalam waktu 18 jam dan jeda istirahat malam selama 6 jam. Hasil penelitian menunjukkan tidak ada perbedaan yang signifikan dalam kadar gula darah yang diukur setiap 4 jam antara kedua kelompok $(p>0,05)$.

\section{Bolus versus Continuous}

Dalam hasil tinjauan sistematis ini terdapat 4 penelitian yang menguji perbandingan pemberian nutrisi enteral dengan metode bolus dengan continuous. Pada penelitian yang dilakukan Seyyedi menunjukkan bahwa tidak ada perbedaan signifikan yang ditemukan antara kelompok continuos dan bolus sebelum dan sesudah intervensi $(p=0,22)$ dan juga satu minggu setelah intervensi $(p=0,14)$, juga tidak terdapat perbedaan yang bermakna antara kadar glukosa dari hari ke 1 sampai hari ke 7 pada kelompok bolus $(p=0,33)$ dan kelompok continuous $(p=0,086)$. Hal ini sejalan dengan penelitian yang dilakukan oleh Evans yang menunjukkan tidak ada perbedaan yang relevan secara klinis dalam variabilitas glikemik, penggunaan insulin, volume tube feeding atau asupan kalori antara kelompok bolus dan continuous. Hasil tersebut didukung pula dalam penelitian Chowdhury bahwa pada kedua metode pemberian nutrisi dengan bolus dan continuous terjadi peningkatan konsentrasi plasma glukosa. Konsentrasi glukosa vena puncak diperoleh pada 30 menit dengan penurunan berikutnya. Hanya ada sedikit peningkatan konsentrasi insulin dengan pemberian continuous dibandingkan dengan bolus.

Berbeda dengan penelitian yang dilakukan oleh Shahriari yang menunjukkan bahwa pada kelompok continuous, rata-rata gula darah menurun secara signifikan pada hari keempat, dibandingkan dengan hari pertama $(p=0,03, \mathrm{~F}=3,85)$ dan ketiga $(p=$ $0,01, \mathrm{~F}=3,15)$. Pada kelompok bolus, rata-rata gula darah meningkat dari hari pertama. Secara signifikan lebih tinggi pada kelompok bolus pada hari kedua $(p=0,02, \mathrm{~F}=3,55)$, dibandingkan dengan kelompok continuous. 


\section{Intermittent versus Continuous}

Dalam hasil pencarian artikel terdapat 3 penelitian yang membandingkan metode intermittent dengan continuous. Pada penelitian Mcnelly menunjukkan bahwa koefisien variasi untuk glukosa plasma konsentrasi lebih tinggi pada intermittent dan lebih banyak hari dengan hiperglikemik yang dilaporkan dengan intermittent feeding daripada continuous feeding dan tidak ada perbedaan dalam jumlah hari dimana hipoglikemik episode terjadi antar kelompok. Selain itu, pada kelompok intermittent feeding menerima sedikit insulin eksogen dalam percobaan 8-10 hari dibanding dengan continuous feeding.

Hal ini sejalan dengan penelitian yang dilakukan Sjulin yang menunjukkan bahwa intermittent feeding dapat menurunkan kebutuhan insulin dibandingkan dengan continuous. Kesinergisan dinamika antara glukosa-insulin ini didukung dalam penelitian Gonzalez yang menyatakan rasio plasma insulin-to-glukagon tetap stabil selama istirahat di tempat tidur dengan intermittent, tetapi meningkat dengan continuous sehingga pada hari ke-6 dan 7, rasio insulin-to-glukagon plasma lebih rendah intermittent dibandingkan continuous. Namun pada hari ketujuh konsentrasi insulin plasma meningkat pada continuous dibandingkan intermittent dan konsentrasi glukagon plasma meningkat pada kelompok intermittent saja.

\section{Sequential versus Continuous}

Dalam penelitian Ren yang menunjukkan bahwa kadar glukosa rata-rata pada sequential feeding tidak lebih tinggi dari pada continuous feeding. Selain itu, insiden hiperglikemia lebih tinggi pada kelompok continuous feeding daripada kelompok sequential feeding serta tidak ada peningkatan intoleransi makan pada sequential feeding. Dapat disimpulkan bahwa sequential feeding seaman continuous feeding untuk pasien sakit kritis.

\section{PEMBAHASAN}

Pada pasien kritis, seringkali mengalami variasi stress metabolisme termasuk penggunaan sumber energi tubuh. Stress adalah istilah dalam ilmu fisiologi dan neuroendrokrinologi untuk merujuk faktor yang menyebabkan ketidakseimbangan pada organisme sehingga mengancam homeostasis. Hal ini terjadi karena asupan terganggu dan terjadi hipermetabolisme dan hiperkatabolisme sehingga kebutuhan energi tubuh meningkat dan terjadi perubahan komposisi tubuh yang dimungkinkan berakhir pada kondisi malnutrisi. Terlebih pada pasien yang memiliki gangguan endokrin sebagai penyakit dasar, maka perlu strategi terapi proaktif yang dapat mengurangi keparahan penyakit, guna mencegah komplikasi dan memberikan hasil akhir yang lebih baik bagi pasien. Oleh karena itu, terapi nutrisi penting diberikan dan menjadi bagian dari terapi klinis pada pasien sakit kritis (Arabi et al., 2017).

Tujuan pemberian nutrisi enteral untuk memenuhi dan melemahkan respon metabolik terhadap stress fisiologis. Diharapkan melalui bantuan nutrisi enteral dapat berperan sebagai farmakoterapi dan kontrol glikemik (Ojo et al., 2019). Modifikasi dari penerapan metode pemberian nutrisi enteral telah banyak dikembangkan. Guna salah satunya sebagai kontrol glikemik. Kontrol glikemik merupakan komponen penting dari manajemen metabolisme pasien kritis. Monitoring kadar glukosa darah secara rutin merupakan prosedur standar di perawatan intensif (Kembuan, 2018). Hal utama dalam manajemen glikemik pada pasien kritis adalah mengidentifikasi target glukosa darah berkisar 140-180 mg/dL. Dalam studi observasional besar, kematian berkurang diamati 
dengan glukosa darah antara 80 dan $140 \mathrm{mg} / \mathrm{dl}$ pada pasien non-diabetes dan 110-180 $\mathrm{mg} / \mathrm{dl}$ pada pasien diabetes (Arabi et al., 2017).

Dalam kontrol glikemik, perlu mengidentifikasi perbedaan hiperglikemik yang terjadi, diantaranya adalah; 1) Perubahan metabolisme glukosa pada pasien kritis akibat stress fisiologis. Hiperglikemia terjadi sebagai respon penyakit atau trauma yang timbul akibat glukoneogenesis hati selama sakit kritis dan menyebabkan peningkatan produksi glukosa. Hal ini melibatkan dua respon sistem metabolisme yakni sitokin dan counterregulatory hormone (epinefrin, norepinefrin, kortisol, glukagon dan growth hormone) yang dilepaskan untuk melawan efek insulin dan hormon anaboliknya. Hormon counterregulatory ini yang akan meningkatkan glukoneogenesis dan katabolisme protein selama stress metabolik. Efeknya insulin yang beredar meningkat, tetapi respon jaringan terhadap insulin terutama di dalam otot menjadi tumpul sehingga terjadi resistensi insulin, perubahan metabolisme karbohidrat dan hiperglikemia. Sebuah penelitian menemukan terjadi peradangan, cedera endotel dan aktivasi koagulasi dilemahkan pada pasien dengan stress hiperglikemia tanpa diabetes tapi tidak pada penderita diabetes; 2) Hiperglikemia yang baru terdiagnosis. Hiperglikemia yang baru terdiagnosis disebabkan oleh pemberian nutrisi enteral yang mengandung glukosa dan glukogenik; 3) Hiperglikemia pada pasien DM pemberian nutrisi enteral harus berdasarkan pada status nutrisi pasien, kesiapan untuk memenuhi nutrisi yang diperkirakan dan fungsi gastrointestinal. Tujuan nutrisi enteral pada pasien dengan DM atau hiperglikemia untuk mengoptimalkan kontrol glikemik, meminimalkan kelainan metabolisme, dan mencegah intoleransi. Indikasi untuk memulai pemberian nutrisi enteral pada pasien dengan DM atau hiperglikemia sama dengan mereka yang tidak menderita DM. Yang membedakan adalah pemberian nutrisi sesuai dengan protokol manajemen insulin (Amaliah, 2021; Arabi et al., 2017).

Berbagai metode pemberian nutrisi enteral telah berkembang sejalan dengan inovasi kecanggihan teknologi kesehatan dan tentunya tidak mengabaikan esensi fisiologis oleh karena kemutakhiran tersebut diaplikasikan kepada manusia. Berdasarkan hasil tinjauan sistematis ini, pengembangan metode pemberian nutrisi enteral dapat memungkinkan memberi manfaat dalam kontrol glikemik dan keseimbangan kadar glukosa darah. Metode pemberian nutrisi enteral diantaranya; 1) continuous feeding; 2) cyclic feeding; 3) intermittent feeding; 4) sequential feeding dan 5) bolus feeding. Jika dilihat dari waktu pemberiannya maka continuous dan cyclic feeding merupakan jenis metode pemberian nutrisi yang secara terus-menerus selama 24 jam yang membedakan adalah terdapat jeda waktu istirahat beberapa jam pada metode cyclic (Ren et al., 2021; Mcnelly et al., 2020).

Pada intermittent, sequential dan bolus merupakan jenis metode pemberian nutrisi secara berselang atau terputus-putus dengan waktu yang telah ditentukan. Hasil penelitian Mcnelly et al., (2020) metode intermittent digunakan 6 kali makan setiap 4 jam selama 24 jam diberikan melalui selang nasogastric menggunakan spuit selama 3-5 menit. Pada metode sequential feeding dalam penelitian Ren et al., (2021) pemberian nutrisi didistribusikan secara merata ketiga periode waktu dengan kecepatan seragam dalam waktu 2 jam yakni pukul 7-9, pukul 11-13 dan pukul 17-19 dari total dosis harian nutrisi enteral sesuai kebutuhan pasien. Serta pada penelitian Maurya et al (2011) dengan metode bolus feeding dilakukan dengan menggunakan spuit $50 \mathrm{~mL}$ secara manual sebanyak 6 kali pemberian berselang 3 jam dalam waktu 18 jam dan jeda istirahat malam selama 6 jam. Ataupun pada penelitian Seyyedi et al., (2020) bolus feeding diberikan melalui nasogastric per 3 jam. 
Keefektifan dari berbagai metode tersebut dalam upaya menjaga keseimbangan kadar glukosa darah atau kontrol glikemik telah dirangkum dalam tinjauan sistematis ini. Penelitian yang dilakukan Murphy et al (2013), membandingkan 1) metode cyclic 2) metode intermittent, dan 3) metode continuous, belum menunjukkan perbedaan dalam kontrol glukosa secara keseluruhan atau perbedaan variabilitas glukosa antara ketiga kelompok tetapi menunjukkan perbedaan dalam tingkat hipoglikemia. Kejadian hipoglikemia lebih sedikit selama periode makan dan terdapat kecenderungan penurunan hipoglikemia selama periode puasa pada kelompok metode intermittent feeding (Murphy et al., 2013). Penelitian yang dilakukan Maurya et al (2011), membandingkan metode cyclic dengan bolus, menunjukkan tidak ada perbedaan yang signifikan dalam kadar gula darah yang diukur setiap 4 jam antara kedua kelompok (P > 0,05) (Maurya et al., 2011).

Penelitian yang dilakukan Seyyedi et al., (2020); Evans et al., (2016) membandingkan antara metode pemberian nutrisi bolus dan continuous, menunjukkan bahwa tidak ada perbedaan signifikan yang ditemukan sampai dengan satu minggu setelah intervensi antara kedua kelompok sebelum dan sesudah intervensi (Seyyedi et al., 2020). Serta tidak ada perbedaan yang relevan secara klinis dalam variabilitas glikemik, penggunaan insulin, volume tube feeding atau asupan kalori antara kelompok bolus dan continuous (Evans et al., 2016).

Berbeda dengan penelitian yang dilakukan oleh Shahriari et al., (2015) yang juga membandingkan antara pemberian nutrisi enteral dengan metode bolus dengan continuous. Hasil menunjukkan pada kelompok continuous, rata-rata gula darah menurun secara signifikan pada hari keempat, dibandingkan dengan hari pertama. Pada kelompok bolus, rata-rata gula darah meningkat dari hari pertama. Pada intervensi terdapat modifikasi meningkatkan volume gavage. Penambahan volume pada kedua kelompok dimaksudkan untuk mencapai volume dan kalori yang telah ditargetkan (Shahriari et al., 2015).

Kecepatan dan volume nutrisi memiliki efek langsung pada pengelolaan glukosa darah. Penelitian menunjukkan bahwa pemberian nutrisi secara continuous mempengaruhi kontrol glikemik melalui pembentukan pola normal sekresi insulin dan glukagon. Asupan zat gizi yang berlebihan dalam satu waktu menyebabkan gula darah meningkat, sedangkan pada pemberian nutrisi secara continuous, kadar gula darah lebih terkontrol (Ojo et al., 2019).

Pemberian nutrisi secara continuous membantu mencapai kontrol glikemik yang lebih baik dan meminimalkan episode disglikemik (Mehta et al., 2019). Selain itu, peningkatan rata-rata glukosa pada kelompok bolus, dipicu oleh makanan enteral disebut efek 'incretin', yang memainkan peran penting dalam regulasi metabolisme glukosa. Mekanisme yang mendasarinya yakni pelibatan pelepasan hormon, seperti Glukosa-dependent Insulinotropic Polypeptide (GIP) dan Glukagon Like Peptide-1 (GLP-1), yang dilepaskan dari mukosa usus ketika glukosa dicerna. Sehingga lonjakan kadar glukosa dapat terjadi setelah pemberian nutrisi dengan metode bolus (Chowdhury et al., 2015).

Hasil yang diperoleh menunjukkan bahwa nutrisi suportif melalui metode continuous berpengaruh terhadap kontrol gula, lebih efektif dalam pengelolaan dan stabilitas gula darah pasien kritis dan membuat status gizi pasien tersebut menjadi lebih baik. Efek positif dari metode pemberian nutrisi secara continuous ini dapat menghasilkan hasil yang sesuai untuk pemulihan pasien dan mengurangi komplikasi (Shahriari et al., 2015). Terlepas dari hasil penelitian dalam tinjauan sistematis ini, para 
peneliti menyarankan bahwa pemberian nutrisi enteral tidak terbatas pada metode mana yang paling efektif oleh karena kekhawatiran terhadap kontrol glikemik, akan tetapi perlu mempertimbangkan faktor lain seperti pemanfaatan sumber daya, kemudahan pemberian nutrisi, dan/atau karakteristik institusi dan pasien.

Manajemen terapi insulin turut mempengaruhi kontrol glikemik, sehingga dalam pemberian nutrisi enteral perlu modifikasi agar pemberian nutrisi dan waktu pemberian insulin dapat tepat guna dan efektif di dalam mengontrol kadar glukosa pasien kritis. Pada penelitian Murphy et al., (2013) metode pemberian nutrisi enteral dengan metode intermittent yang diberikan 3 kali dengan durasi selama 4 jam per satu kali pemberian nutrisi dikombinasikan dengan insulin analog kerja pendek dan insulin analog kerja panjang di malam hari.

Penelitian yang dilakukan Evans et al., (2016) memodifikasi terapi insulin diberikan setiap 6 jam untuk mencegah kadar glukosa darah $>120 \mathrm{mg} / \mathrm{dL}$. Infus insulin secara kontinu mungkin dimulai jika pasien memiliki dua glukosa darah berturut-turut yang kadarnya $>200 \mathrm{mg} / \mathrm{dL}$ atau atas intruksi ahli intensif dalam pengaturan hiperglikemia persisten. Insulin protokol infus digerakkan oleh perawat dan dititrasi setiap jam berdasarkan nilai glukosa darah saat ini dan sebelumnya, dengan kisaran sasaran 110-150 mg/dl.

Penelitian Sjulin et al., (2020) menyatakan bahwa penurunan kebutuhan insulin terjadi ketika pasien diberikan nutrisi secara intermittent dari pada continuous. Dinamika ini mendukung keefektifan pemberian nutrisi enteral untuk mencegah disglikemia dan penatalaksanaan terapi insulin pada pasien kritis untuk kebutuhan insulin yang lebih rendah dibanding metode continuous. Sebuah studi klinis small crossover clinical study menunjukkan bahwa pasien dengan stress hiperglikemia memerlukan lebih sedikit insulin setelah pemberian nutrisi enteral secara intermitten.

Hal ini didukung pula dalam penelitian Mcnelly et al., (2020) metode intermittent menerima sedikit insulin eksogen dalam percobaan 8-10 hari dibanding dengan continuous feeding. Hal ini sejalan dengan penelitian Sjulin et al., (2020) bahwa dinamika glukosa-insulin pada pasien kritis yang membutuhkan infus insulin untuk mempertahankan konsentrasi glukosa antara 140-180 mg/dl dengan pemberian nutrisi melalui metode intermittent feeding dapat menurunkan kebutuhan insulin dibandingkan dengan continuous. Kesinergisan dinamika antara glukosa-insulin ini didukung dalam penelitian Gonzalez et al., (2020) yang menyatakan rasio plasma insulin-to-glukagon tetap stabil selama istirahat di tempat tidur dengan intermittent, tetapi meningkat dengan continuous sehingga pada hari ke-6 dan 7, rasio insulin-to-glukagon plasma lebih rendah intermittent dibandingkan continuous.

Pemberian nutrisi dengan metode intermittent feeding hampir mirip dengan metode sequential feeding baik waktu, durasi dan siklus pemberian nutrisinya. Hasil penelitian menunjukkan kadar glukosa rata-rata pada sequential feeding tidak lebih tinggi dari pada continuous feeding. Selain itu, insiden hiperglikemia lebih tinggi pada kelompok continuous feeding daripada kelompok sequential feeding (Ren et al., 2021)

Jenis dan komposisi nutrisi yang diberikan pun memegang peranan penting di dalam kontrol glikemik, sehingga perlu perhitungan kebutuhan nutrisi dan kalori yang tepat untuk pasien kritis dengan berkolaborasi dengan ahli gizi dan dokter spesialis gizi. Dalam penelitian Murphy et al., (2013) semua pasien diberi makan formula standar 1 $\mathrm{kkal} / \mathrm{mL}$ untuk memenuhi perkiraan kebutuhan nutrisi. Begitu pula dengan nutrisi yang diberikan dalam penelitian Maurya et al., (2011) yang memberikan energi setara dengan $1 \mathrm{kkal} / \mathrm{mL}$. Nutrisi disiapkan $220 \mathrm{~mL}$, enam sendok takar $(53,4 \mathrm{~g})$ bubuk formula 
ditambahkan secara bertahap dan dicampur dalam $190 \mathrm{~mL}$ air dalam gelas. Sedangkan pada penelitian Shahriari et al., (2015) dengan memberikan enchur powder yang terdiri dari tujuh gelas takar yang dicampur dengan $90 \mathrm{cc}$ air dan menghasilkan $100 \mathrm{cc}$ nutrisi. Jumlah total kalori dan volume yang dibutuhkan dihitung oleh ahli gizi melalui persamaan Harris-Benedict, dan kondisi pasien.

\section{SIMPULAN}

Pemberian nutrisi enteral dengan metode continuous dapat menurunkan rata-rata kadar glukosa darah atau mengurangi kejadian hiperglikemia. Kemudian pemberian nutrisi enteral dengan metode intermittent secara signifikan lebih sedikit terjadi hipoglikemia selama periode makan, mencegah hipoglikemia selama periode puasa serta dapat menurunkan kebutuhan insulin. Manajemen terapi insulin turut mempengaruhi kontrol glikemik, sehingga dalam pemberian nutrisi enteral perlu modifikasi agar pemberian nutrisi dan waktu pemberian insulin dapat tepat guna dan efektif didalam mengontrol kadar glukosa pasien kritis.

\section{SARAN}

Terlepas dari beberapa hasil penelitian lain dalam tinjauan sistematis ini, para peneliti menyarankan bahwa pemberian nutrisi enteral tidak terbatas pada metode mana yang paling efektif oleh karena kekhawatiran terhadap variabilitas glikemik, akan tetapi perlu mempertimbangkan faktor lain seperti pemanfaatan sumber daya, kemudahan pemberian nutrisi, dan/atau karakteristik institusi dan pasien.

\section{DAFTAR PUSTAKA}

Amaliah, A. (2021). Karakteristik Klinis Pasien Hiperglikemia Non Diabetes yang Dirawat di Perawatan Intensif. Universitas Hasanuddin. http://repository.unhas.ac.id/id/eprint/2634/

Anggorotomo, W., \& Kestriani, N. D. (2020). Nutrisi Enteral pada Pasien Kritis di Intensive Care Unit (ICU). Jurnal Ilmiah Widya Kesehatan Dan Lingkungan, 2(1), 25-32. https://e-journal.jurwidyakop3.com/index.php/kes-ling/article/view/406

Arabi, Y. M., Casaer, M. P., Chapman, M., Heyland, D. K., Ichai, C., Marik, P. E., \& Weijs, P. J. M. (2017). The Intensive Care Medicine Research Agenda in Nutrition and Metabolism. Intensive Care Medicine, 43(9), 1239-1256. https://doi.org/10.1007/s00134-017-4711-6

Bear, D. E., Hart, N., \& Puthucheary, Z. (2018). Continuous or Intermittent Feeding: Pros and Cons. Curr Opin Crit Care, 24(4), 256-261. https://doi.org/10.1097/MCC.0000000000000513

Chowdhury, A. H., Murray, K., Hoad, C. L., Costigan, C., Marciani, L., Macdonald, I. A., \& Frcpe, Ã. (2015). Effects of Bolus and Continuous Nasogastric Feeding on Gastric Emptying, Small Bowel Water Content, Superior Mesenteric Artery Blood Flow, and Plasma Hormone Concentrations in Healthy Adults. Annals of Surgery, 263(3), 450-457. https://doi.org/10.1097/SLA.0000000000001110

Dewi, Y. S., \& Supriatna, M. (2021). Perbedaan Lama Rawat dan Luaran Pemberian Nutrisi Enteral Dini dan Lambat pada Anak Sakit Kritis di Rumah Sakit dr. Kariadi Semarang. Sari Pediatri, 22(6). DOI: 10.14238/sp22.6.2021.378-85 
Evans, D. C., Forbes, R., Jones, C., Cotterman, R., Njoku, C., Thongrong, C., \& Stawicki, S. P. (2016). Continuous Versus Bolus Tube Feeds : Does the Modality Affect Glycemic Variability, Tube Feeding Volume, Caloric Intake, or Insulin Utilization? International Journal of Critical Illness and Injury Science, 6(1), 915. https://doi.org/10.4103/2229-5151.177357

Ferrie, S., Daniells, S., Gagnon, S., Hamlyn, J., Jukkola, K., Riley, N., \& Zarshenas, N. (2018). Enteral Nutrition Manual for Adults in Health Care Facilities. Melbourne: Dietitians Association of Australia Nutrition Support Interest Group. Retrieved from https://dietitiansaustralia.org.au/wp-content/uploads/2018/06/Enteralnutrition-manual-june-2018-website.pdf

Gonzalez, J. T., Dirks, M. L., Holwerda, A. M., Kouw, I. W. K., \& Loon, L. J. C. Van. (2020). Intermittent Versus Continuous Enteral Nutrition Attenuates Increases in Insulin and Leptin During Short - Term Bed Rest. European Journal of Applied Physiology, 120(9), 2083-2094. https://doi.org/10.1007/s00421-020-04431-4

Hutagaol, R., \& Hamidi, N. S. (2020). Efektifitas Pemberian Nutrisi Enteral antara Metode Intermittent Feeding dengan Gravity Drip terhadap Volume Residu Lambung pada Pasien Kritis di Ruangan ICU Aulia Hospital Pekanbaru. Jurnal Kesehatan Tambusai, 1(4), 24-33. https://journal.universitaspahlawan.ac.id/index.php/jkt/article/view/1512

Ichimaru, S. (2018). Methods of Enteral Nutrition Administration in Critically Ill Patients : Continuous, Intermittent, Cyclic, and Bolus Feeding Methods of EN $\begin{array}{llll}\text { Administration. Nutr Clin } \quad \text { Pract, } & \text { 33(6), }\end{array}$ https://doi.org/10.1002/ncp.10105

Kembuan, M. A. H. N. (2018). Disglicemia Relationship with Critical Patient Outside in Room Intermediate Care Neurology RSUP Prof. R. D. Kandou Manado. Jurnal Sinaps, 1(1), 1-8. http://jurnalsinaps.com/index.php/sinaps/article/view/8

Mahakrishna, B. N., Wati, D. K., Hartawan, I. N. B., Bagus, I., \& Suparyatha, G. (2020). Hubungan Tipe Pemberian Nutrisi dengan Luaran Pasien dan Lama Rawat Pasien Acute Respiratory Distress Syndrome yang Dirawat di Unit Perawatan Intensif Anak RSUP Sanglah. Medicina, 51(1), 17-22. https://doi.org/10.15562/Medicina.v51i1.387

Maurya, I., Pawar, M., Garg, R., Kaur, M., \& Sood, R. (2011). Comparison of Respiratory Quotient and Resting Energy Expenditure in Two Regimens of Enteral Feeding - Continuous vs. Intermittent in Head-Injured Critically Ill Patients, 5(2), 195-202. https://doi.org/10.4103/1658-354X.82800

Mcnelly, A. S., Bear, D. E., Connolly, B. A., Arbane, G., Allum, L., Tarbhai, A., \& Puthucheary, Z. A. (2020). Effect of Intermittent or Continuous Feed on Muscle Wasting in Critical Illness a Phase 2 Clinical Trial. Chest, 158(1), 183-194. https://doi.org/10.1016/j.chest.2020.03.045

Mehta, Y., Mithal, A., Kulkarni, A., Reddy, B. R., Sharma, J., Dixit, S., \& Zirpe, K. (2019). Practice Guidelines for Enteral Nutrition Management in Dysglycemic Critically Ill Patients : A Relook for Indian Scenario. Indian Journal of Critical Care Medicine, 23(12), 594-603. 10.5005/jp-journals-10071-23298

Murphy, P. M., Moore, E., \& Flanagan, D. E. (2013). Glycaemic Control in Insulin Requiring Diabetes Patients Receiving Exclusive Enteral Tube Feeding in an Acute Hospital Setting. Diabetes Research and Clinical Practice, 103(3), 426429. https://doi.org/10.1016/j.diabres.2013.12.007 
Ojo, O., Weldon, S. M., Thompson, T., Crockett, R., \& Wang, X. (2019). Nutrients the Eff ect of Diabetes-Specific Enteral Nutrition Formula on Cardiometabolic Parameters in Patients with Type 2 Diabetes: A Systematic Review and Meta Analysis of Randomised Controlled Trials. Nutrient, 11(8), 1905.DOI: 10.3390/nu11081905

Ren, C., Yao, B., Tuo, M., Lin, H., Wan, X., \& Pang, X. (2021). Comparison of Sequential Feeding and Continuous Feeding on the Blood Glucose of Critically Ill Patients: A Non-Inferiority Randomized Controlled Trial. Chinese Medical Journal, O(14), 1695-1700. https://doi.org/10.1097/CM9.0000000000001684

Seyyedi, J., Rooddehghan, Z., Mohammadi, M., \& Haghani, S. (2020). Comparison of the Effect of Enteral Feeding through the Bolus and Continuous Methods on Serum Phosphorus and Glucose Levels in Patients with Mechanical Ventilation: A Randomized Clinical Trial. J Nutr Metab, 8. DOI: 10.1155/2020/6428418

Shahriari, M., Rezaei, E., Bakht, L. A., \& Abbasi, S. (2015). Comparison of the Effects of Enteral Feeding Through the Bolus and Continuous Methods on Blood Sugar and Prealbumin Levels in ICU Inpatients. Journal of Education and Health Promotion, 4(December). https://doi.org/10.4103/2277-9531.171809

Sjulin, T. J., Strilka, R. J., Huprikar, N. A., Cameron, L. A., Woody, P. W., \& Armen, S. B. (2020). Intermittent Gastric Feeds Lower Insulin Requirements without Worsening Dysglycemia: A Pilot Randomized Crossover Trial. International Journal of Critical Illness \& Injury Science, 10(4), 200-205. https://doi.org/doi: 10.4103/IJCIIS.IJCIIS_112_19

Taslim, N. A., Primana, D. A., Wijayanto, Rani, N. A., Marniar, Bamahry, A., \& Virani, D. (2020). Panduan Praktis Penatalaksanaan Nutrisi COVID-19. Jakarta: Perhimpunan Dokter Spesialis Gizi Klinik Indonesia 